\title{
Antifouling by pre-deposited Al hydrolytic flocs on ultrafiltration membrane in the presence of humic acid and bovine serum albumin
}

\author{
Baiwen $\mathrm{Ma}^{\mathrm{a}}$, Xing Wang ${ }^{\mathrm{a}, \mathrm{b}}$, Chengzhi $\mathrm{Hu}^{\mathrm{a}, *}$, William A. Jefferson ${ }^{\mathrm{a}}$, Huijuan $\mathrm{Liu}^{\mathrm{a}}$, Jiuhui Qu ${ }^{\mathrm{a}}$ \\ ${ }^{a}$ Key Laboratory of Drinking Water Science and Technology, Research Center for Eco-Environmental Sciences, Chinese Academy of Sciences, Beijing 100085, China \\ b University of Chinese Academy of Sciences, Beijing 100049, China
}

\section{A R T I C L E I N F O}

\section{Keywords:}

Ultrafiltration membrane

Humic acid and bovine serum albumin

Al-based flocs

Pre-deposition

Fouling alleviation

\begin{abstract}
A B S T R A C T
Pre-deposition technology is a promising method for alleviating membrane fouling, and in situ hydrolytic flocs have strong adsorption ability. In comparison with iron salts, less corrosiveness is induced by aluminum salts. Here, flocs formed by aluminum salts were pre-deposited onto the surface of an ultrafiltration (UF) membrane, aimed at investigating the antifouling performance with humic acid (HA) or bovine serum albumin (BSA). The results showed that Al-based flocs were well distributed onto the membrane surface, and a relatively dense and homogeneous deposition layer was formed. Both HA and BSA could largely be adsorbed/rejected by the predeposited layer during filtration. In comparison to results for solution $\mathrm{pH}$ of 8.0, the floc layer was much denser with a larger surface specific area and smaller average pore diameter at $\mathrm{pH}$ 6.0. Due to the existence of $\mathrm{Al}_{13}$ species, a more positively charged floc layer occurred at lower $\mathrm{pH}$ values, leading to stronger adsorption abilities toward the negatively charged HA and BSA molecules. The floc layer significantly reduced the possibility of HA and BSA molecules reaching the UF membrane, which helped alleviate membrane fouling under lower $\mathrm{pH}$ conditions. Furthermore, the results for effluent with $\mathrm{pH}$ between 6.0 and 8.0 showed that the removal efficiency of HA molecules with small molecular weight $(<3 \mathrm{kDa})$ was also higher, especially at $\mathrm{pH} 6.0$.
\end{abstract}

\section{Introduction}

Ultrafiltration (UF) membranes have been applied in water treatment worldwide, due to the better effluent quality obtained even with varying feed-water properties. Membrane fouling is, however, inevitable because the membrane pores will gradually adsorb and be blocked by particles, followed by cake layer formation during filtration [1-4]. Larger molecular weight (MW) organic matter, such as humic substances and proteins, always tend to induce serious UF membrane fouling to some extent, owing to the pore blocking and cake layer formation [5-9].

To alleviate membrane fouling effectively, three membrane processes combined with adsorption technology have been investigated to remove pollutants: (1) pre-adsorption process, in which a sedimentation tank is required after adsorption and the adsorbents are deposited before the membrane system; (2) direct-filtration process, in which raw water is flowed into the membrane tank directly after adsorption; (3) pre-deposition process, in which adsorbent layers are pre-deposited onto the membrane surface before filtration $[10,11]$.

The first two processes have been investigated in detail, and have already been applied in many water plants. However, the last process has only been tested in the laboratory with flat sheet microfiltration/ ultrafiltration membranes $[12,13]$. In comparison with the pre-adsorption process, the pre-deposition process further reduces land use, owing to the lack of a need for sedimentation. Additionally, serious membrane fouling is often caused when using the pre-adsorption process because of the higher chance of membrane pore blocking after the sedimentation process [14]. For the direct-filtration process, larger sludge discharge always occurs due to the lack of a sedimentation tank. Compared with the other two processes, the pre-deposition technology has demonstrated much better removal of organic compounds $[11,15]$.

Up to now, various kinds of adsorption materials have been coated or layered onto the surface of membranes to investigate their adsorption/rejection properties with various target pollutants, and less membrane fouling was indeed observed. However, the use of powdered activated carbon (PAC) alone could cause severe membrane damage by shearing the membrane surface, especially after long running time [16], while the high cost of other adsorbents prohibited their use in actual operations, for example carbon nanotubes (CNTs) [13], heated iron oxide particles (HIOPs) [17], heated aluminum oxide particles (HAOPs) [18], nanoscale zerovalent iron (NZVI) [19], and so on. In addition, some adsorbents were found to exhibit preferential removal ability

\footnotetext{
* Corresponding author.

E-mail address: czhu@rcees.ac.cn (C. Hu).
} 
toward specific pollutants, while performing worse on removal of other types. It has been demonstrated that PAC preferentially adsorbs many non-fouling natural organic matter (NOM) molecules during filtration [18].

It is known that aluminum salts and iron salts have been successfully used in drinking water and wastewater treatment, and their favorable performance is due to the strong adsorption capability of their flocs [20-22]. For the combined process of coagulation and UF membrane, Al-based and Fe-based flocs have been shown to play an important role in alleviating membrane fouling [7,14,22]. In comparison to iron salts, however, aluminum salts have lower corrosiveness in water treatment $[22,23]$. In addition, humic substances and proteins are formed by the decomposition of plants/animals and are commonly present in natural waters $[7,24,25]$. The concentration of humic substances and proteins are in the range of a few $\mathrm{mg} / \mathrm{L}$ to a few hundred mg/L C $[26,27]$. Owing to their large molecular weight distributions and physical properties, severe UF membrane fouling is inevitably induced $[19,28,29]$. Herein, this study focuses on an UF membrane with pre-deposited Al-based flocs, aiming to understand the characteristics of membrane fouling caused by humic substances and proteins. Furthermore, some influencing factors were also investigated, such as dosage and solution $\mathrm{pH}$, and the membrane fouling alleviation mechanisms were elucidated finally.

\section{Materials and methods}

\subsection{Chemical reagents}

All chemicals used were analytical reagent grade unless otherwise specified, and the stock solutions were prepared using deionized (DI) water (Millipore, Milli-Q). Humic acid sodium salt (HA, Aldrich, USA) is typically used to represent HS $[6,19]$, and was stored in the dark at $4{ }^{\circ} \mathrm{C}(10 \mathrm{~g} / \mathrm{L})$. Bovine serum albumin (BSA, Sinopharm Chemical Reagent, Co., Ltd, China; $67 \mathrm{kDa}$ ) is usually used as a representative of protein [30]. It was dissolved in a phosphate-buffered salt solution (PBS, composed of $0.03 \mathrm{M} \mathrm{Na}_{2} \mathrm{HPO}_{4} \cdot 12 \mathrm{H}_{2} \mathrm{O}$ and $0.03 \mathrm{M} \mathrm{KH}_{2} \mathrm{PO}_{4}$ ) and was used within $8 \mathrm{~h}$ [31]. The concentration of BSA stock solution was also $10 \mathrm{~g} / \mathrm{L}$, and $0.02 \mathrm{M} \mathrm{AlCl}_{3} \cdot 6 \mathrm{H}_{2} \mathrm{O}$ solution was freshly prepared each time.

\subsection{UF membrane process}

A polyvinylidene fluoride (PVDF) flat sheet UF membrane was used with a molecular weight cut-off (MWCO) of $100 \mathrm{kDa}$. The membranes were obtained from Tianjin Motimo Membrane Tech. Co., Ltd, China. All membranes were firstly immersed in DI water for $24 \mathrm{~h}$, and the water was changed three times. To keep membrane flux constant, fresh

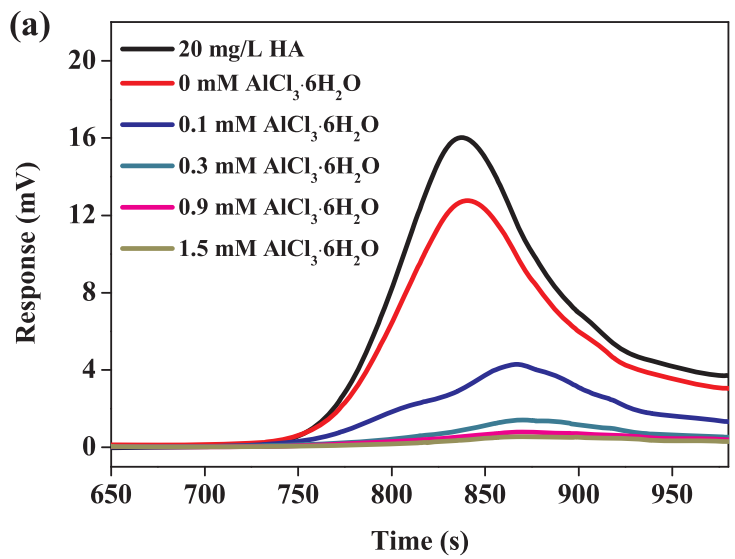

membranes were firstly filtrated with DI water $(300 \mathrm{~mL})$. The Millipore UF stirred cell (Amicon 8400, USA) was driven by $\mathrm{N}_{2}$, which was maintained at $0.1 \mathrm{MPa}$ during filtration.

For the tests, the aluminum solution was diluted by DI water to the specific concentration with $\mathrm{NaHCO}_{3}(0.1 \mathrm{M}, 3 \mathrm{~mL})$ as buffer. The final solution $\mathrm{pH}$ was determined by prior addition of a corresponding amount of $\mathrm{HCl}$ or $\mathrm{NaOH}(0.1 \mathrm{M})$. In order to form flocs gradually, the rapid mixing of $300 \mathrm{rpm}$ lasted for $1 \mathrm{~min}$, while the slow mixing of $100 \mathrm{rpm}$ lasted for $14 \mathrm{~min}$. Afterward, the stirrer was taken out carefully, and the UF cell was maintained under static conditions to let the Al-based flocs settle naturally (20 min), forming a homogeneous layer on the membrane surface. Finally, the corresponding HA or BSA stock solution was added into the aforementioned water, and allowed to dissolve completely by keeping the cell static for $30 \mathrm{~min}$.

\subsection{Floc size measurement}

A beaker $(1.0 \mathrm{~L})$ with a flocculator device was used in the jar tests without HA or BSA. $300 \mathrm{rpm}$ (rapid mixing) was maintained for $1 \mathrm{~min}$, followed by decreasing the speed to $100 \mathrm{rpm}$ for another $14 \mathrm{~min}$ to allow flocs to grow. The properties of flocs were measured by a laser particle size analyzer (Mastersizer 2000, Malvern, UK) during the coagulation process, including particle size and fractal dimension $\left(D_{f}\right)$. The particle size of flocs was automatically recorded by computer every $0.5 \mathrm{~min}$. Fractal dimension was measured by using small anglelight scattering $[32,33]$, which has been successfully used in previous studies [34,35]. Moreover, the specific surface area of the Al-based flocs was analyzed by the Brunauer-Emmett-Teller method (BET, ASAP2020HD88).

\subsection{Other measurement methods}

An Orion pH meter (USA) was used to measure the solution $\mathrm{pH}$; The variation of membrane flux as a function of time was recorded by computer; The zeta potential was analyzed by a Malvern Zetasizer 2000 (UK); The concentration of HA or BSA and the MW distributions were measured by gel permeation chromatography (GPC, Agilent Technologies, USA); The morphology of the membrane surface was measured by scanning electron microscopy (SEM, JEOL Ltd., Tokyo, Japan). The average pore size of the pre-layered membrane was analyzed by ImageJ software, which measured the apparent pore size on the surface (without considering the 3-dimensional structure of the membrane and Al-based floc layer) [13].

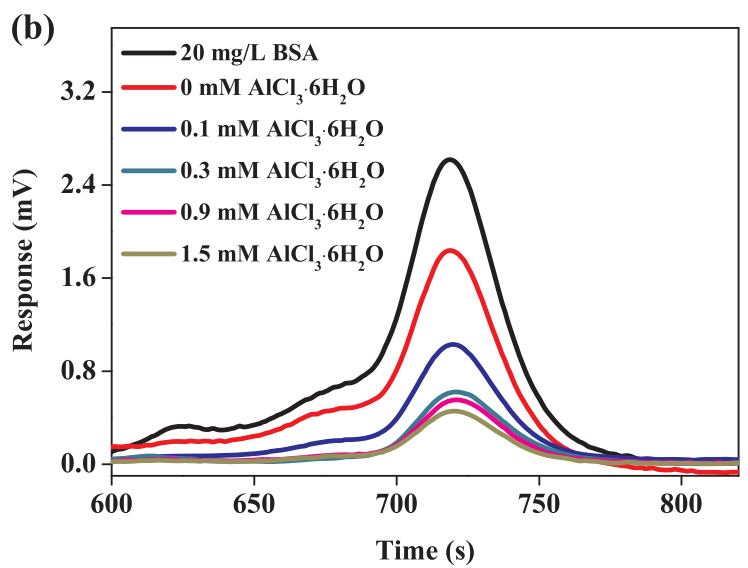

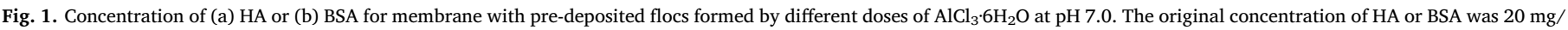
L. 

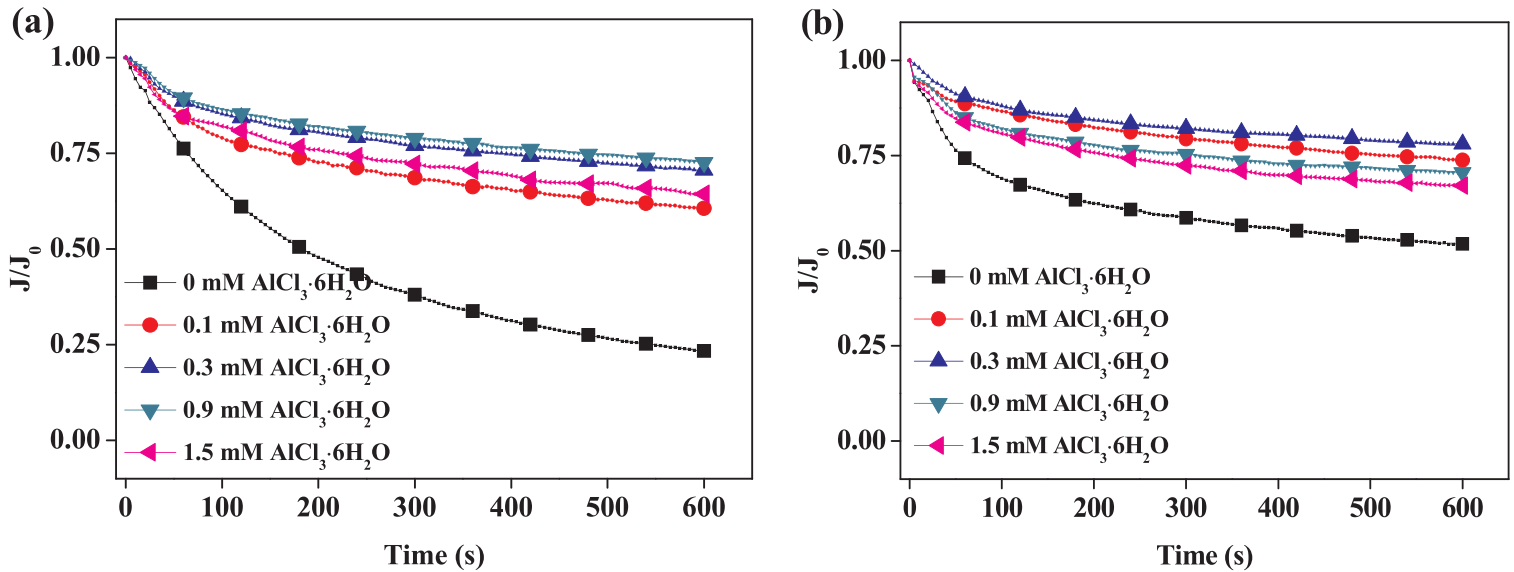

Fig. 2. Membrane specific flux caused by $\mathrm{HA}$ or BSA for membrane with pre-deposited flocs formed by different doses of $\mathrm{AlCl}_{3} \cdot 6 \mathrm{H}_{2} \mathrm{O}$ at $\mathrm{pH} 7.0$ : (a) $20 \mathrm{mg} / \mathrm{L} \mathrm{HA}$; (b) $20 \mathrm{mg} / \mathrm{L} \mathrm{BSA}$
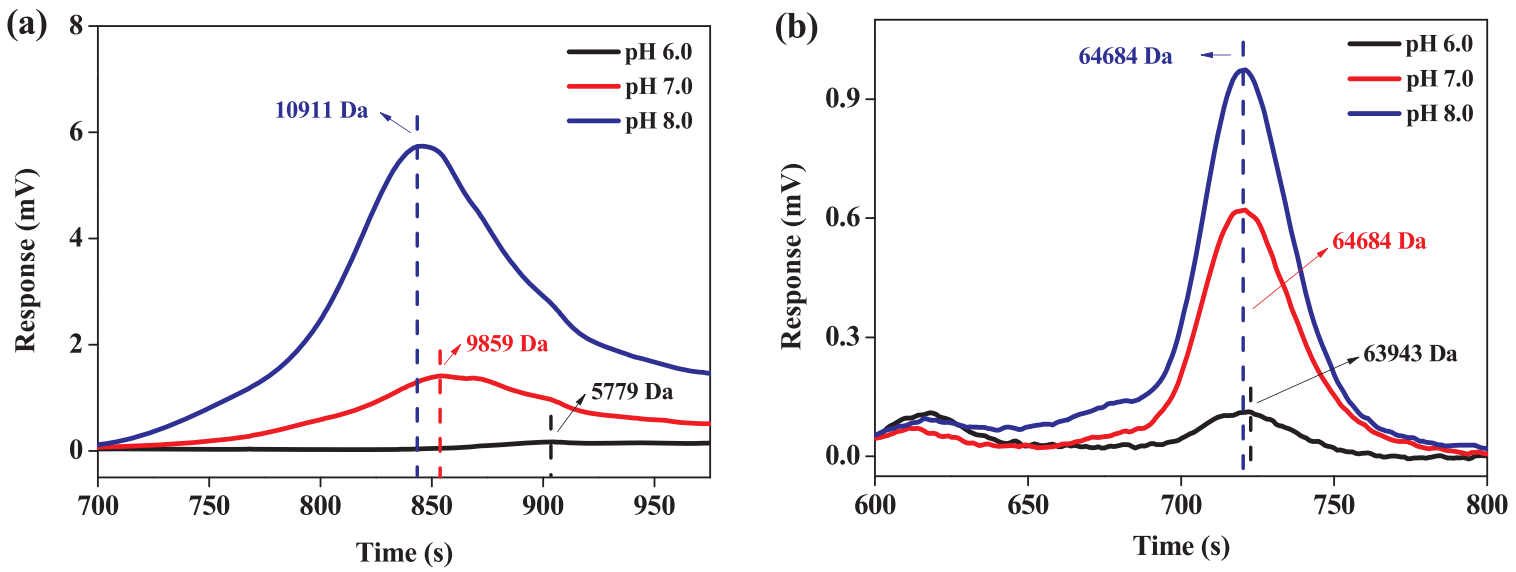

Fig. 3. Variation of the concentration and peak value with flocs formed by $0.3 \mathrm{mM} \mathrm{AlCl} \mathrm{Al}_{3} \cdot 6 \mathrm{H}_{2} \mathrm{O}$ in effluent under different pH conditions: (a) $20 \mathrm{mg} / \mathrm{L} \mathrm{HA}$; (b) $20 \mathrm{mg} / \mathrm{L} \mathrm{BSA}$.

\section{Results}

\subsection{Effect of floc dosage and backwashing}

To investigate the removal properties, different dosages of flocs were deposited onto the UF membrane surface. The variations of HA or BSA concentrations before and after filtration are shown in Fig. 1. The results showed that the concentration of HA or BSA in the effluent gradually decreased with increasing dose of flocs. The removal rate of HA was $20.3 \%$ when there were no flocs deposited onto the membrane surface, while the rate increased to $73.2 \%, 91.2 \%, 95.1 \%$ and $96.5 \%$ in the presence of flocs formed by $0.1,0.3,0.9$ and $1.5 \mathrm{mM} \mathrm{AlCl}_{3} \cdot 6 \mathrm{H}_{2} \mathrm{O}$, respectively. For BSA, however, $29.8 \%$ was removed by the UF membrane alone. When flocs were pre-layered onto the UF membrane surface, the removal efficiency of BSA was $60.7 \%, 76.3 \%, 78.8 \%$ and $82.4 \%$ in the presence of flocs formed by $0.1,0.3,0.9$ and $1.5 \mathrm{mM}$ $\mathrm{AlCl}_{3} \cdot 6 \mathrm{H}_{2} \mathrm{O}$. Fig. 1 clearly shows that both $\mathrm{HA}$ and BSA molecules were largely removed by the pre-deposited membrane, especially the wide MW range HA molecules.

With the removal of HA or BSA by the pre-deposited flocs during filtration, the corresponding membrane specific flux increased (Fig. 2). For comparison, the membrane specific flux induced by HA or BSA was investigated in the absence of flocs at $\mathrm{pH}$ 7.0. The results showed that the final membrane specific flux (600 s, similarly hereinafter) induced by $20 \mathrm{mg} / \mathrm{L}$ HA or BSA was 0.23 or 0.52 . For HA, however, the final membrane specific fluxes increased to $0.61,0.71,0.73$ and 0.64 in the presence of flocs formed by $0.1,0.3,0.9$ and $1.5 \mathrm{mM} \mathrm{AlCl} \cdot 6 \mathrm{H}_{2} \mathrm{O}$. For $\mathrm{BSA}$, the corresponding final membrane specific fluxes increased to $0.74,0.78,0.70$ and 0.67 , respectively. Although both the membrane specific fluxes improved, pre-deposited Al-based flocs could alleviate membrane fouling better in the presence of HA. As seen from Fig. 1, the final membrane specific flux increased 0.48 for $\mathrm{HA}$ with flocs formed by $0.3 \mathrm{mM} \mathrm{AlCl} \cdot 6 \mathrm{H}_{2} \mathrm{O}$, and only increased 0.26 for BSA.

In addition, backwashing is one of the main running conditions, and the "dynamic" pre-layered membrane was investigated by pushing $10 \mathrm{~mL}$ permeate at a roughly flowrate after filtering half feed water. Fig. S1 shows that little variation was observed before and after backwashing in the presence of $0.3 \mathrm{mM} \mathrm{AlCl} \cdot 6 \mathrm{H}_{2} \mathrm{O}$ and $20 \mathrm{mg} / \mathrm{L} \mathrm{HA}$ at $\mathrm{pH}$ 7.0. The possible reason was due to the strong adhesion force between the pre-layered floc layer and the UF membrane. Similar results have been observed in previous studies $[13,19]$.

\subsection{Effect of solution $p H$}

Characteristics of flocs were significantly influenced by solution $\mathrm{pH}$ $[36,37]$. To understand the properties of membrane fouling under different $\mathrm{pH}$ conditions, fouling experiments were investigated between $\mathrm{pH} 6.0$ and 8.0 when flocs were formed by $0.3 \mathrm{mM} \mathrm{AlCl} \mathrm{Al}_{3} \cdot 6 \mathrm{H}_{2} \mathrm{O}$ (similarly hereinafter). Fig. 3 presents the variation of the concentration and the corresponding peak values as a function of $\mathrm{pH}$. The removal rate of $\mathrm{HA}$ was $98.9 \%$ at $\mathrm{pH} 6.0$, while the rates were gradually reduced to $91.2 \%$ and $64.2 \%$ at pH 7.0 and 8.0 , respectively. For BSA, however, the removal rates were $95.8 \%, 76.3 \%$ and $62.7 \%$ at $\mathrm{pH} 6.0,7.0$ and 8.0.

With the rejection of HA or BSA, the MW distribution peak values in effluent decreased. The peak values of HA and BSA molecules alone were $11,826 \mathrm{Da}$ and $66,496 \mathrm{Da}$. After filtration, the values were reduced to 5779, 9859 and 10,911 Da for $\mathrm{HA}$ at $\mathrm{pH}$ 6.0, 7.0 and 8.0. Compared with HA, less variation occurred regarding the peak values of the BSA MW distribution in effluent, which were 63943, 64,684 and 64,684 $\mathrm{Da}$ at $\mathrm{pH}$ 6.0, 7.0 and 8.0. 

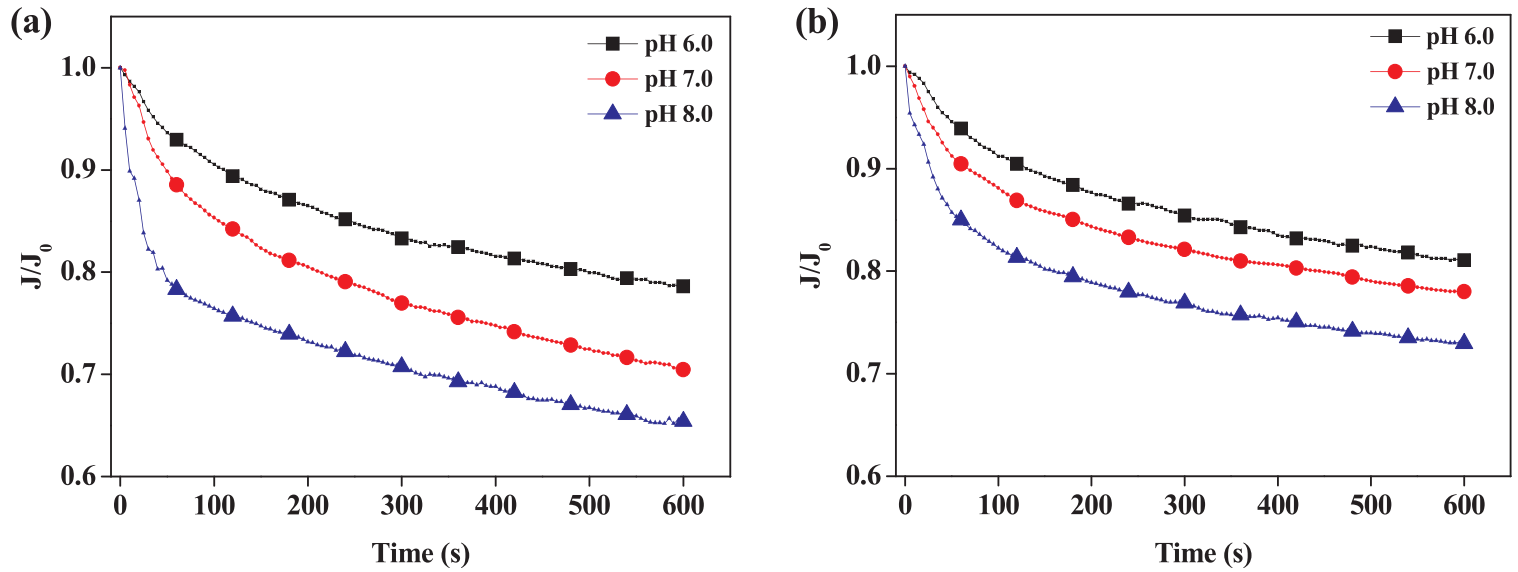

Fig. 4. Membrane specific flux for pre-deposited flocs formed by $0.3 \mathrm{mM} \mathrm{AlCl} \mathrm{Al}_{3} \cdot 6 \mathrm{H}_{2} \mathrm{O}$ under different $\mathrm{pH}$ conditions: (a) $20 \mathrm{mg} / \mathrm{L} \mathrm{HA}$; (b) $20 \mathrm{mg} / \mathrm{L} \mathrm{BSA}$.

As seen from Fig. 3, both HA and BSA molecules were largely removed at $\mathrm{pH} 6.0$, resulting in less possibility of HA or BSA molecules reaching the UF membrane. Thus, less serious membrane fouling occurred (Fig. 4). For HA, the final membrane specific fluxes were $0.79,0.71$ and 0.65 at $\mathrm{pH} 6.0,7.0$ and 8.0. For BSA, the final membrane specific fluxes were $0.81,0.78$ and 0.73 at $\mathrm{pH} 6.0,7.0$ and 8.0, respectively. The membrane specific flux induced by $20 \mathrm{mg} / \mathrm{L}$ HA or

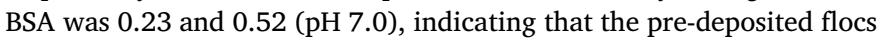
could improve membrane specific flux more for HA in comparison to BSA.

\subsection{HA MW fraction in effluent}

A previous study showed that the HA MW distribution ranges from a few thousands to hundreds of thousands of Daltons [6]. As seen in Figs. 1a and 3a, a higher removal rate of HA occurred, and the corresponding peak value was also dramatically changed. To investigate the properties of HA removal, the MW results in effluent as a function of $\mathrm{pH}$ were investigated and are shown in Fig. 5.

In contrast, the results from the original PVDF membrane are shown at $\mathrm{pH}$ 7.0. Fig. 1a shows that the removal rate of HA by the membrane alone was only $20.3 \%$. The removal rate of HA molecules with large MW ( $>30 \mathrm{kDa}$ ) was $37.2 \% \pm 2.3 \%$, while the removal rates of HA molecules with medium MW (3-30 kDa) and small MW ( $<3 \mathrm{kDa})$ were $17.8 \% \pm 1.2 \%$ and $5.9 \% \pm 0.7 \%$, respectively. However, as seen from Figs. 1a and $3 \mathrm{a}$, the deposited layer provided a large advantage in removing/rejecting HA molecules, especially in acidic solution. For $\mathrm{pH}$ 6.0, The specific removal rate of HA molecules with large MW (> $30 \mathrm{kDa}$ ) was $99.4 \% \pm 0.9 \%$, and the removal rates of HA molecules

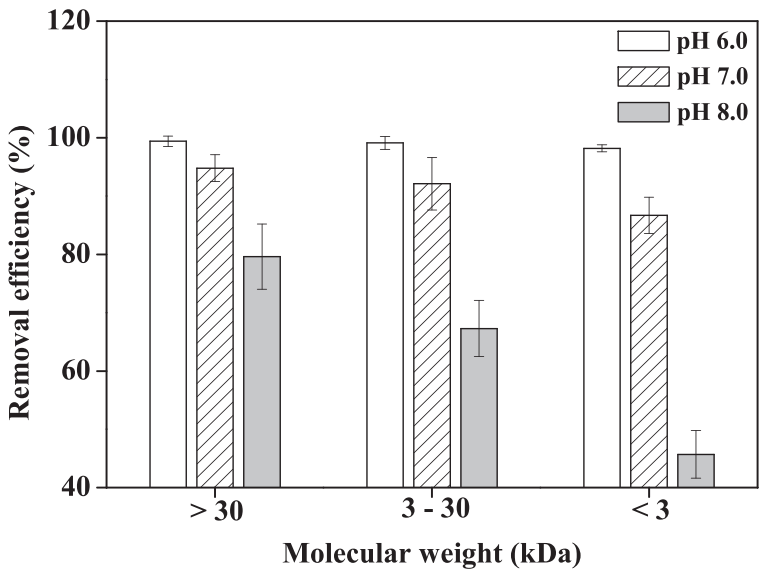

Fig. 5. Removal rate of different molecular weight HA molecules with flocs formed by $0.3 \mathrm{mM} \mathrm{AlCl}_{3} \cdot 6 \mathrm{H}_{2} \mathrm{O}$ at $\mathrm{pH} 6.0,7.0$ and 8.0 . with medium MW (3-30 kDa) and small MW ( $<3 \mathrm{kDa})$ were $99.1 \% \pm 1.1 \%$ and $98.2 \% \pm 0.6 \%$, respectively. With rising solution $\mathrm{pH}$, relatively fewer HA molecules were removed by the floc layer. Therefore, the removal rate of HA molecules with large MW ( $>30 \mathrm{kDa}$ ) was reduced to $79.4 \% \pm 5.6 \%$ at $\mathrm{pH} 8.0$, while the rates for medium MW (3-30 kDa) and small MW $(<3 \mathrm{kDa})$ were reduced to $67.3 \% \pm 4.8 \%$ and $45.9 \% \pm 4.1 \%$. Fig. 5 clearly shows that different MW distribution HA molecules were largely removed at $\mathrm{pH}$ 6.0.

Because the properties of flocs were significantly influenced by solution $\mathrm{pH}$, the removal rates of HA molecules with different MW distributions also varied. Compared with $\mathrm{pH}$ 8.0, smaller differences were observed in the removal rate between large MW HA molecules $(>30 \mathrm{kDa})$ and small MW HA molecules $(<3 \mathrm{kDa})$ at $\mathrm{pH}$ 6.0. The difference in the removal rate regarding the large MW HA molecules ( $>30 \mathrm{kDa}$ ) and small MW HA molecules $(<3 \mathrm{kDa}$ ) was only $1.2 \%$ at $\mathrm{pH}$ 6.0, and was significantly higher at $33.5 \%$ at $\mathrm{pH}$ 8.0.

\section{Discussion}

It has been reported that serious fouling is caused by pore blocking for porous UF membranes [38]. Owing to the variation in the HA MW distribution [6], severe fouling was always induced during filtration. The BSA used was electrophoresis pure and its molecular weight was about $67 \mathrm{kDa}$, which was smaller than the membrane pores $(100 \mathrm{kDa})$. Thus, most BSA molecules passed through the membrane pores, causing less severe membrane fouling.

When flocs formed by $\mathrm{Al}$ hydrolysis were pre-deposited onto the membrane surface, HA and BSA molecules could be removed by the pre-deposited layer. It has been demonstrated that homogeneous deposition layers always perform better due to the UF membrane being more exposed to the solution with a heterogeneous layer [13]. The surface morphology of the virgin and pre-deposited membranes was investigated in the presence of brown HA (Fig. 6; morphology of the colorless BSA is not shown in the absence/presence of the predeposition layer). As seen from Fig. 6a and b, homogeneous aluminum floc deposition layers were formed at $\mathrm{pH}$ 7.0. Thus, HA and BSA molecules could largely be removed in the presence of flocs, especially with the much denser pre-deposited layer formed at $\mathrm{pH} 6.0$ (Fig. S2). With increasing floc dosage, the pre-deposited layer became thicker, leading to more HA and BSA molecules being adsorbed/rejected. Owing to the different properties of HA and BSA, the removal efficiency of HA was higher (Fig. 1), and will be discussed later.

Fig. S3 shows that the membrane fouling induced by flocs alone was more severe with a larger dose of flocs at $\mathrm{pH}$ 7.0. Therefore, the membrane specific flux induced by HA or BSA increased first and decreased thereafter with increased floc dosage (Fig. 2), even though more HA or BSA molecules were rejected. On the other hand, Fig. 1 shows that more HA molecules were removed than BSA molecules. As a 

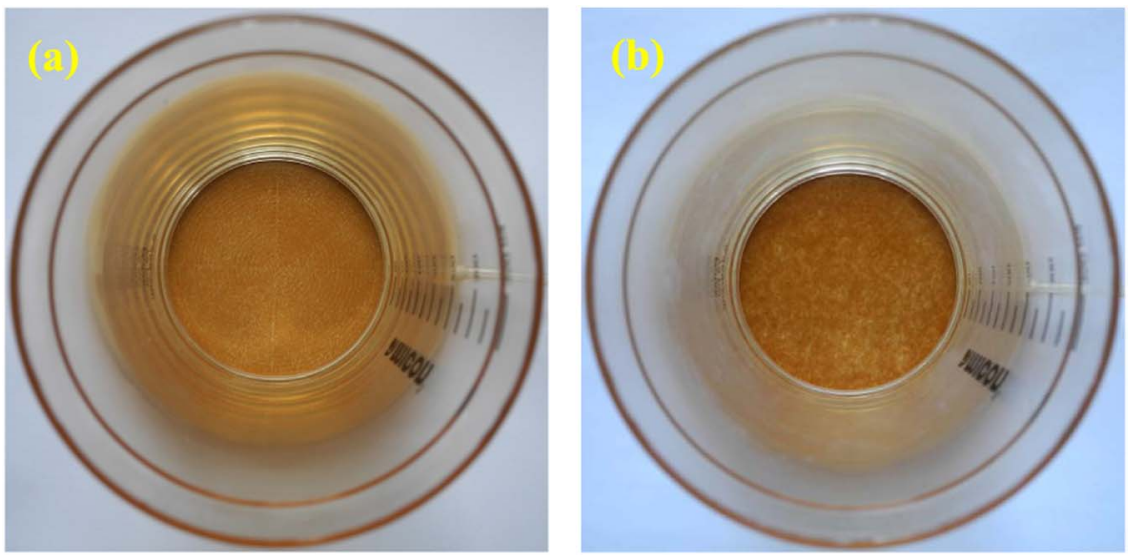

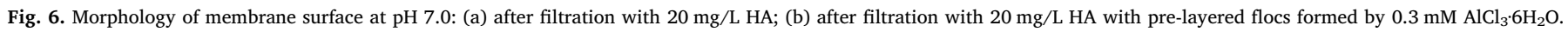
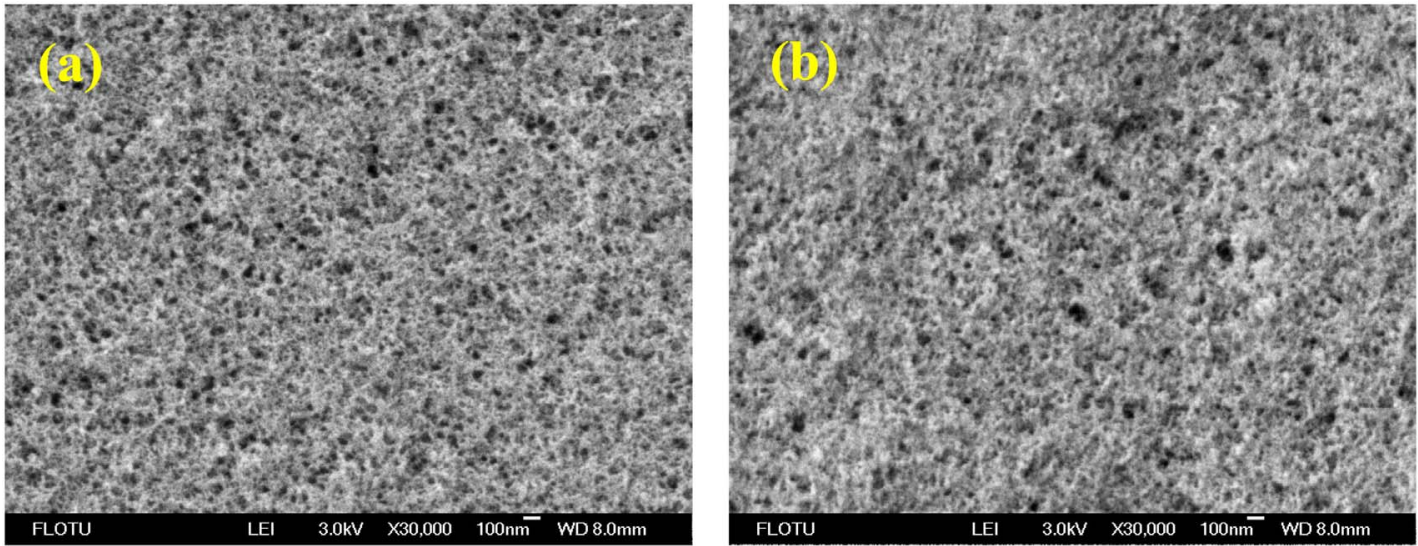

Fig. 7. SEM of the floc layer formed by $0.3 \mathrm{mM} \mathrm{AlCl}{ }_{3} \cdot 6 \mathrm{H}_{2} \mathrm{O}$ at: (a) $\mathrm{pH} 6.0$; (b) $\mathrm{pH} 8.0$.

(a)

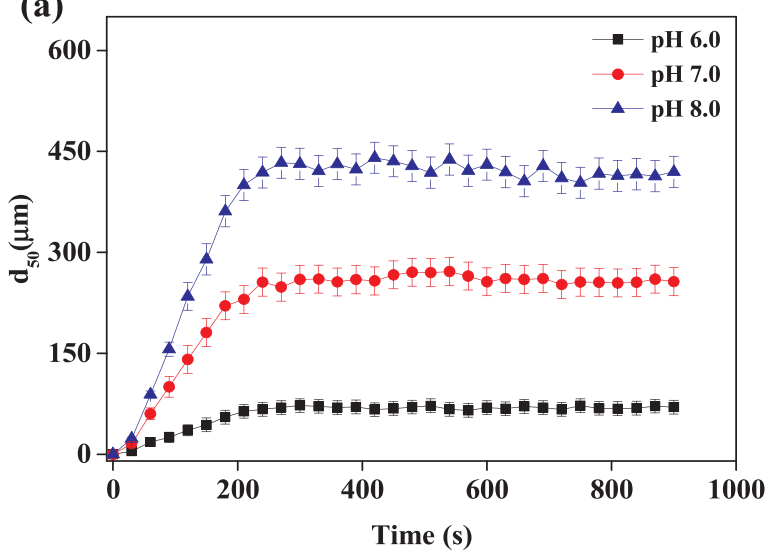

(b)

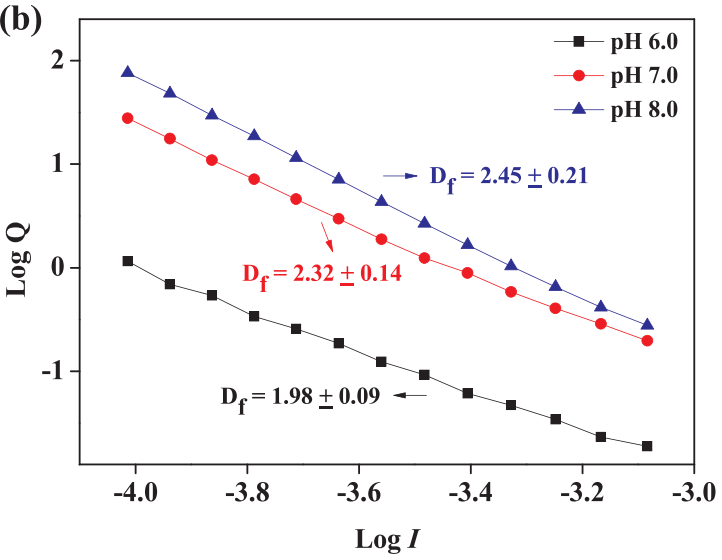

Fig. 8. Characteristics of flocs formed by $0.3 \mathrm{mM} \mathrm{AlCl}_{3} \cdot 6 \mathrm{H}_{2} \mathrm{O}$ at $\mathrm{pH} 6.0,7.0$ and 8.0: (a) particle size; (b) fractal dimension.

result, the pre-deposited membrane performed much better in the presence of HA (Fig. 2).

SEM of the pre-coated membrane surface was investigated to further understand the specific properties of the pre-deposited layer (Fig. 7). It was observed that relatively uniform deposition layers were formed on the membrane surface under different $\mathrm{pH}$ conditions (Fig. 7a and b). However, the pre-deposited layer formed at $\mathrm{pH} 6.0$ was a little denser than that formed at $\mathrm{pH}$ 8.0. The average pore diameter of the predeposited layer was $9.47 \pm 0.18 \mathrm{~nm}$ at $\mathrm{pH} 6.0$, while it increased to $11.36 \pm 0.07 \mathrm{~nm}$ at $\mathrm{pH} 8.0$. Therefore, the chance of rejecting HA or BSA molecules was higher under lower $\mathrm{pH}$ conditions, especially the large MW HA molecules ( $>30 \mathrm{kDa}$ ).
Solution $\mathrm{pH}$ significantly influenced the morphology of the precoated membrane surface $[36,37]$. As shown in Fig. 8, the median size $\left(d_{50}\right)$ of flocs rapidly increased during the early coagulation period $\left(<4 \mathrm{~min}\right.$ ) at $\mathrm{pH} 6.0,7.0$ and 8.0. The $\mathrm{d}_{50}$ value increased to a maximum value after $5 \mathrm{~min}$. However, it can be seen that the $d_{50}$ value at lower $\mathrm{pH}$ values was much smaller compared to that at higher $\mathrm{pH}$ values. The specific $d_{50}$ value of the flocs was $60.3 \pm 10.2 \mu \mathrm{m}$ at $\mathrm{pH} 6.0$, while it was $422.3 \pm 23.1 \mu \mathrm{m}$ at $\mathrm{pH}$ 8.0. The floc fractal dimension was $2.45 \pm 0.21$ at $\mathrm{pH}$ 8.0, which was larger than that at $\mathrm{pH} 6.0$ $(1.98 \pm 0.09)$. Although larger fractal dimension flocs were more easily compressed $[39,40]$, the morphology of the membrane surface was denser at $\mathrm{pH} 6.0$ (Fig. 7a). A potential reason for the difference at $\mathrm{pH}$ 


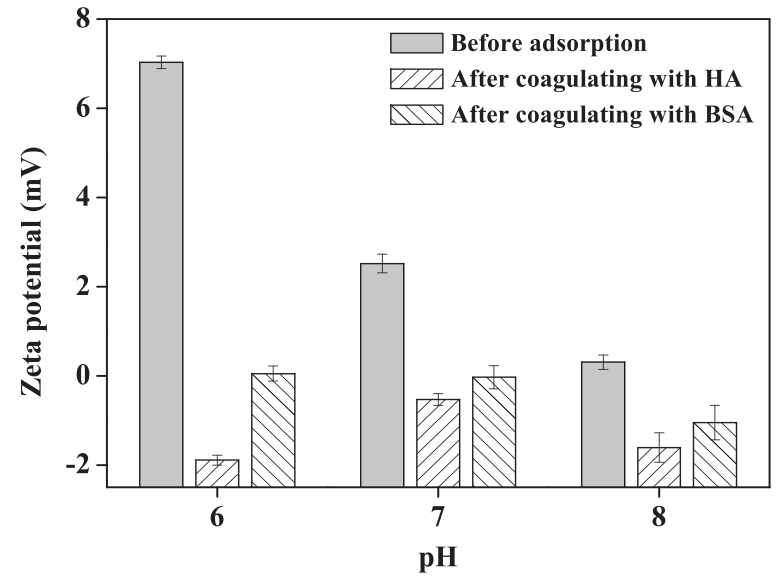

Fig. 9. Zeta potential of flocs formed by $0.3 \mathrm{mM} \mathrm{AlCl} 3 \cdot 6 \mathrm{H}_{2} \mathrm{O}$ before and after coagulation with $\mathrm{HA}(20 \mathrm{mg} / \mathrm{L})$ or BSA $(20 \mathrm{mg} / \mathrm{L})$ under different $\mathrm{pH}$ conditions.

6.0 might be due to the much smaller particle size flocs, which were roughly one seventh the particle size of the flocs at $\mathrm{pH}$ 8.0. In fact, the smaller floc particle size also led to larger specific surface area, which was $297.1 \pm 28.3 \mathrm{~m}^{2} / \mathrm{g}$ at $\mathrm{pH} 6.0$, and $247.6 \pm 19.8 \mathrm{~m}^{2} / \mathrm{g}$ at $\mathrm{pH} 8.0$. All the aforementioned characteristics of the pre-deposited layer indicated a larger adsorption/rejection ability at $\mathrm{pH} 6.0$, despite the relatively thin layer formed (Fig. S4).

The adsorption ability of flocs was also analyzed to understand the fouling mechanism in detail (Fig. 9). A previous study demonstrated that the flocs formed by $\mathrm{AlCl}_{3} \cdot 6 \mathrm{H}_{2} \mathrm{O}$ at $\mathrm{pH} 6.0$ contained in-situ formed positively charged $\mathrm{Al}_{13}$ polymer $\left(\left[\mathrm{Al}_{13} \mathrm{O}_{4}(\mathrm{OH})_{24}\left(\mathrm{H}_{2} \mathrm{O}\right)_{12}\right]^{7+}\right)$, and these flocs exhibited higher adsorption ability [41]. The zeta potentials of flocs alone were $7.03 \pm 0.14 \mathrm{mV}(\mathrm{pH} 6.0), 2.52 \pm 0.21 \mathrm{mV}(\mathrm{pH} \mathrm{7.0)}$ and $0.31 \pm 0.16 \mathrm{mV}$ (pH 8.0). It was determined that both HA and BSA molecules were negatively charged between $\mathrm{pH} 6.0$ and $\mathrm{pH}$ 8.0. The corresponding zeta potentials of HA were $-0.43 \pm 0.08,-0.83 \pm 0.05$ and $-1.74 \pm 0.16 \mathrm{mV}$ at $\mathrm{pH} 6.0,7.0$ and 8.0. The corresponding zeta potentials of BSA were $-0.33 \pm 0.06,-0.58 \pm 0.19$ and $-1.12 \pm 0.15 \mathrm{mV}$ at $\mathrm{pH} 6.0,7.0$ and 8.0, respectively. Therefore, more HA or BSA molecules were adsorbed by the flocs under lower $\mathrm{pH}$ conditions, especially more negative HA molecules (Fig. 9). Additionally, it has been found that HA molecules could make fuller use of the active adsorption sites of flocs in comparison to BSA molecules, due to the wide MW distribution [7]. Thus, the pre-deposited layer alleviated the membrane fouling induced by HA better compared to that of BSA under different $\mathrm{pH}$ conditions (Figs. 1 and 4).
Regarding the removal rate of HA molecules, the UF membrane alone could not reject HA molecules effectively because of the large membrane pore diameter $(100 \mathrm{kDa})$. When Al-based flocs were prelayered onto the UF membrane surface, large MW HA molecules ( $>30 \mathrm{kDa}$ ) and medium MW HA molecules (3-30 kDa) were easily removed because of the dense pre-deposited layer, leading to higher removal efficiency. However, the floc layer was relatively dense and electropositive, leading to more small MW HA molecules being $(<3 \mathrm{kDa})$ removed, especially at $\mathrm{pH} 6.0$.

Based on the foregoing observations, the properties of the floc layer played an important role in the UF membrane performance. The larger the dose of Al-based flocs, the thicker the layer and higher removal efficiency induced. For the same total amount of flocs, the characteristics of the pre-deposited layer played an important role in the higher removal efficiency, such as the properties of density and uniformity. The larger specific surface area and higher positive zeta potentials of the pre-deposited layer were also key factors in removing HA and BSA molecules. Owing to the more negatively charged and wide MW range HA molecules, the corresponding removal rate was higher than that of BSA molecules. The specific schematic diagram of the pre-deposited membrane removing pollutants and resisting membrane fouling is illustrated in Fig. 10.

Although HA and BSA molecules could be largely removed by the pre-deposited layer, they would break through and membrane fouling could still be serious when the concentration of HA or BSA was higher than the maximum adsorption capacity. To fully understand the antifouling properties of the pre-deposited UF membrane, further research will be focused on hollow fiber UF membranes to investigate the practicability at pilot scale, in which the flocs are suspended in the membrane tank with aeration from the bottom.

\section{Conclusions}

Aluminum salts have been successfully applied in water treatment, and pre-deposition technology is a promising method for alleviation of membrane fouling. This study focused on the performance of membranes with pre-deposited in situ flocs formed by aluminum salts in the presence of humic substances or proteins. The overall findings are as follows:

1. Al-based flocs were well distributed onto the membrane surface, and had strong adsorption/rejection abilities, resulting in significant alleviation of membrane fouling. With increased pre-deposited floc dosage, the pre-deposited layer was thicker and higher removal
HA BSA

\section{Al-based flocs}
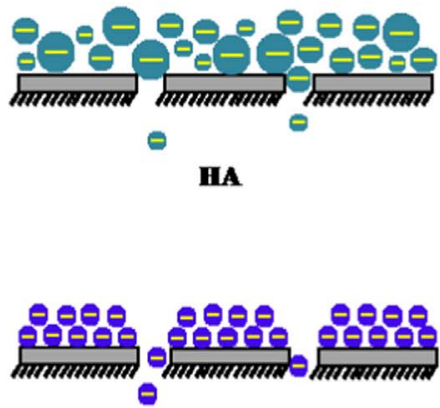

BSA
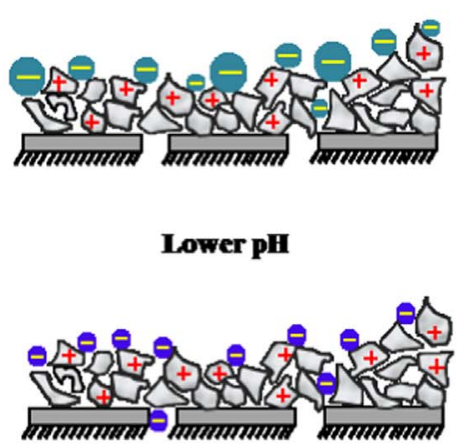

Lower pH

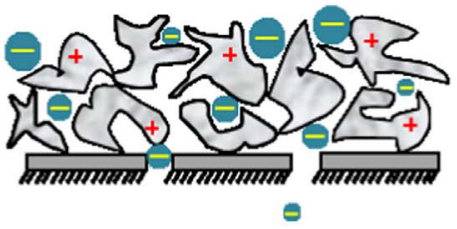

Higher pH

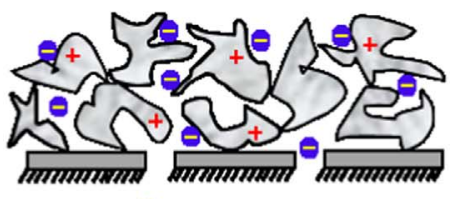

$\theta$

Fig. 10. Schematic diagram of the removal of HA and BSA by the pre-deposited layer under different pH conditions. 
efficiency was induced.

2. Solution $\mathrm{pH}$ significantly influenced the properties of the predeposited layer. Owing to the smaller floc size under lower $\mathrm{pH}$ conditions, a denser deposition layer was formed with larger specific surface area. Additionally, the corresponding pre-deposited layer had a higher positive charge and smaller pore diameter, all of which indicated stronger adsorption abilities.

3. HA molecules with large MW ( $>30 \mathrm{kDa}$ ) were much more easily rejected by the pre-layered flocs. In comparison to the removal rate of HA molecules with large MW ( $>30 \mathrm{kDa}$ ), the removal rate of small MW HA molecules $(<3 \mathrm{kDa})$ was also higher, especially under lower $\mathrm{pH}$ conditions.

\section{Acknowledgments}

This work was supported by the State Key Program of the National Natural Science Foundation of China (Grant Nos. 51138008 and 51378490). This work was also supported by the National Natural Science Foundation for Young Scientists of China (51608514).

\section{Appendix A. Supplementary material}

Supplementary data associated with this article can be found in the online version at http://dx.doi.org/10.1016/j.memsci.2017.05.029.

\section{References}

[1] J.Y. Tian, M. Ernst, F.Y. Cui, M. Jekel, Effect of particle size and concentration on the synergistic UF membrane fouling by particles and NOM fractions, J. Membr. Sci. 446 (2013) 1-9.

[2] G. Amy, Fundamental understanding of organic matter fouling of membranes, Desalination 231 (2009) 44-51.

[3] H.C. Kim, B.A. Dempsey, Membrane fouling due to alginate, SMP, EfOM, Humic acid and NOM, J. Membr. Sci. 428 (2013) 190-197.

[4] R.H. Peiris, M. Jaklewicz, H. Budan, R.L. Legge, C. Moresoli, Assessing the role of feed water constituents in irreversible membrane fouling of pilot-scale ultrafiltration drinking water treatment systems, Water Res. 47 (2013) 3364-3374.

[5] X. Zhang, R.B. Bai, Y.W. Tong, Selective adsorption behaviors of proteins on polypyrrole-based adsorbents, Sep. Purif. Technol. 52 (2006) 161-169.

[6] W. Yuan, A.L. Zydeny, Humic acid fouling during ultrafiltration, Environ. Sci. Technol. 34 (2000) 5043-5050.

[7] B.W. Ma, W.Z. Yu, H.J. Liu, J.B. Yao, J.H. Qu, Effect of iron/aluminum hydrolyzed precipitate layer on ultrafiltration membrane, Desalination 330 (2013) 16-21.

[8] H. Guo, Y. Wyar, J. Perot, F. Naulear, P. Moulin, Low-pressure membrane for integrity tests for drinking water treatment: a review, Water Res. 44 (2010) 41-57.

[9] Y.S. Polyakov, A.L. Zydney, Ultrafiltration membrane performance: effects of pore blockage/constriction, J. Membr. Sci. 434 (2013) 106-120.

[10] B. Malczewska, J. Liu, M.M. Benjamin, Virtual elimination of MF and UF fouling by adsorptive pre-coat filtration, J. Membr. Sci. 479 (2015) 159-164.

[11] Z.X. Cai, M.M. Benjamin, NOM fractionation and fouling of low-pressure membranes in microgranular adsorptive filtration, Environ. Sci. Technol. 45 (2011) 8935-8940.

[12] R. Thiruvenkatachari, W.G. Shim, J.W. Lee, R.B. Aim, H. Moon, A novel method of powdered activated carbon (PAC) pre-coated microfiltration (MF) hollow fiber hybrid membrane for domestic wastewater treatment, Colloids Surf. A 274 (2006) 24-33.

[13] G.S. Ajmani, D. Goodwin, K. Marsh, D.H. Fairbrother, K.J. Schwab, J.G. Jacangelo, H.O. Huang, Modification of low pressure membranes with carbon nanotube layers for fouling control, Water Res. 46 (2012) 5645-5654.

[14] W.Z. Yu, J.H. Qu, J. Gregory, Pre-coagulation on the submerged membrane fouling in nano-scale: effect of sedimentation process, Chem. Eng. J. 262 (2015) 676-682.
[15] J. Kim, Z.X. Cai, M.M. Benjamin, NOM fouling mechanisms in a hybrid adsorption/ membrane system, J. Membr. Sci. 349 (2010) 35-43.

[16] Z.X. Cai, C. Wee, M.M. Benjamin, Fouling mechanism in low-pressure membrane filtration in the presence of an adsorbent cake layer, J. Membr. Sci. 433 (2013) 32-38.

[17] M.M. Zhang, C. Li, M.M. Benjamin, Y.J. Chang, Fouling and natural organic matter removal in adsorbent/membrane systems for drinking water treatment, Environ. Sci. Technol. 37 (2003) 1663-1669.

[18] J. Kim, Z.X. Cai, M.M. Benjamin, Effects of adsorbents on membrane fouling by natural organic matter, J. Membr. Sci. 310 (2008) 356-364.

[19] B.W. Ma, W.Z. Yu, W.A. Jefferson, H.J. Liu, J.H. Qu, Modification of ultrafiltration membrane with nanoscale zerovalent iron layers for humic acid fouling reduction, Water Res. 71 (2015) 140-149.

[20] K. McCurdy, K. Carlson, D. Gregory, Floc morphology and cyclic shearing recovery: comparison of alum and polyaluminum chloride coagulants, Water Res. 38 (2004) 486-494.

[21] M.K. Korbutowicz, Effect of $\mathrm{Al}$ coagulant type on natural organic matter removal efficiency in coagulation/ultrafiltration process, Desalination 185 (2005) 327-333.

[22] M. Umar, F. Roddick, L.H. Fan, Comparison of coagulation efficiency of aluminum and ferric-based coagulants as pre-treatment for UVC/ $\mathrm{H}_{2} \mathrm{O}_{2}$ treatment of wastewater RO concentrate, Chem. Eng. J. 284 (2016) 841-849.

[23] D. Eaves, G. Williams, H.N. McMurray, Inhibition of self-corrosion in magnesium by poisoning hydrogen recombination on iron particles, Electrochem. Acta 79 (2012) 1-7.

[24] S.A. Baghoth, S.K. Sharma, G.L. Amy, Tracking natural organic matter (NOM) in a drinking water treatment plant using fluorescence excitation-emission matrices and PARAFAC, Water Res. 45 (2011) 797-809.

[25] J.Y. Tian, M. Ernst, F.Y. Cui, M. Jekel, Effect of different cations on UF membrane fouling by NOM, Chem. Eng. J. 223 (2013) 547-555.

[26] N.A. Wall, G.R. Choppin, Humic acids coagulation: influence of divalent cations, Appl. Geochem. 18 (2003) 1573-1582.

[27] A. Saxena, B.P. Tripathi, M. Kumar, V.K. Shahi, Membrane-based techniques for the separation and purification of proteins: an overview, Adv. Colloid Interface Sci. 145 (2009) 1-22.

[28] D. Kuzmenko, E. Arkhangelsky, S. Belfer, V. Freger, V. Gitis, Chemical cleaning of UF membranes fouled by BSA, Desalination 179 (2005) 323-333.

[29] F. Xiao, P. Xiao, W.J. Zhang, D.S. Wang, Identification of key factors affecting the organic fouling on low pressure ultrafiltration membranes, J. Membr. Sci. 447 (2013) 144-152.

[30] E. Arkhangelsky, F. Wicaksana, C.Y. Tang, A.A. Al-Rabiah, S.M. Al-Zahrani, R. Wang, Combined organic-inorganic fouling of forward osmosis hollow fiber membranes, Water Res. 46 (2012) 6329-6338.

[31] L. Palacio, C.C. Ho, P. Pradanos, A. Hernandez, A.L. Zydney, Fouling with protein mixtures in microfiltration: BSA-lysozyme and BSA-pepsin, J. Membr. Sci. 222 (2003) 41-51.

[32] T.D. Waite, J.K. Cleaver, J.K. Beattie, Aggregation kinetics and fractal structure of $\gamma^{-}$ alumina assemblages, J. Colloid Interface Sci. 241 (2001) 333-339.

[33] R.M. Wu, D.J. Lee, T.D. Waite, J. Guan, Multilevel structure of sludge flocs, J. Colloid Interface Sci. 252 (2002) 383-392.

[34] P. Jarvis, B. Jefferson, S.A. Parson, Breakage, re-growth, and fractal nature of natural organic matter flocs, Environ. Sci. Technol. 39 (2005) 2307-2314.

[35] W.Z. Yu, C.Z. Hu, H.J. Liu, J.H. Qu, Effect of dosage strategy on Al-humic flocs growth and regrowth, Colloid Surf. A 404 (2012) 106-111.

[36] B.Q. Zhao, D.S. Wang, T. Li, C.W.K. Chow, C. Huang, Influence of floc structure on coagulation-microfiltration performance: effect of Al speciation characteristics of PACls, Sep. Purif. Technol. 72 (2010) 22-27.

[37] L.J. Feng, W.Y. Wang, R.Q. Feng, S. Zhao, H.Y. Dong, S.L. Sun, B.Y. Gao, Q.Y. Yue, Coagulation performance and membrane fouling of different aluminum species during coagulation/ultrafiltration combined process, Chem. Eng. J. 262 (2015) 1161-1167.

[38] F. Wang, V.V. Tarabara, Pore blocking mechanism during early stages of membrane fouling by colloids, J. Colloid Interface Sci. 328 (2008) 464-469.

[39] E.J. Roth, B. Gilbert, D.C. Mays, Colloid deposit morphology and clogging in porous media: fundamental insights through investigation of deposit fractal dimension, Environ. Sci. Technol. 49 (2015) 12263-12270.

[40] W.Z. Yu, N. Graham, H.J. Liu, J.H. Qu, Comparison of $\mathrm{FeCl}_{3}$ and alum pretreatment on UF membrane fouling, Chem. Eng. J. 234 (2013) 158-165.

[41] C.Z. Hu, G.X. Chen, H.J. Liu, H. Zhao, J.H. Qu, Characterization of flocs generated by preformed and in situ formed $\mathrm{Al}_{13}$ polymer, Chem. Eng. J. 197 (2012) 10-15. 